\title{
Geological Observations from a Palaeolake Basin, Lamayuru, Ladakh, Northwestern Himalaya
}

\author{
Vikram Sharma, A. R. Chaudhri \\ Department of Geology, Kurukshetra University, Kurukshetra, India \\ Email: sharmav12@kuk.ac.in, archaudhri@gmail.com
}

How to cite this paper: Sharma, V. and Chaudhri, A.R. (2021) Geological Observations from a Palaeolake Basin, Lamayuru, Ladakh, Northwestern Himalaya. Open Journal of Geology, 11, 175-182. https://doi.org/10.4236/ojg.2021.116010

Received: April 2, 2021

Accepted: June 5, 2021

Published: June 8, 2021

Copyright $\odot 2021$ by author(s) and Scientific Research Publishing Inc. This work is licensed under the Creative Commons Attribution International License (CC BY 4.0).

http://creativecommons.org/licenses/by/4.0/

\section{(c) (i) Open Access}

\begin{abstract}
A well known Buddhist monastery of Lamayuru is located in a village about $128 \mathrm{Km}$ West of Leh. It is situated on more than $100 \mathrm{~m}$ thick Late Quaternary palaeolake deposits which are surrounded by rocks of Lamayuru Formation. Geologically, the Lamayuru Formation includes the Lamayuru and Namikala flysch deposits of Triassic-Jurassic age. This Formation is composed of shales, schist and phyllites. This Lamayuru Formation forms the base and source of palaeolake deposits. In Late-Pleistocene (35 ka B.P.) the Lamayuru River was dammed due to tectonically triggered landslide and the Lamayuru palaeolake came into existence. The sedimentation in the palaeolake basin commenced at $35 \mathrm{ka} \mathrm{B.P.} \mathrm{and} \mathrm{culminated} \mathrm{at} 1 \mathrm{ka} \mathrm{B.P.} \mathrm{The} \mathrm{deposits} \mathrm{of} \mathrm{palaeolake} \mathrm{consist} \mathrm{of}$ carbonaceous mud, sand, silty clay and matrix supported breccia. The palaeolake deposits are a product of complex interplay of lacustrine, fluvio-deltaic to colluvial processes. The research study shows the prevalence of glacio-lacustrine conditions during the major part of depositional history as evidenced by the dominance of varves in these deposits.
\end{abstract}

\section{Keywords}

Late-Quaternary, Lamayuru Formation, Palaeolake Deposits, NW Himalaya

\section{Introduction}

The rocks around Lamayuru lake deposits are composed of Lamayuru and Namikala flysch comprising sandstone, shale, limestone and volcanic tuffs [1]. These rocks, Triassic to Jurassic in age, serve as the basement as well as the source rocks for the palaeolake sediments. The rocks occur as a thrust slice sandwiched between Shergol ophiolite in the north and Mesozoic of the Tethys 
Himalayas of Zanskar in the south [2]. Developed in the main valley along the Indus Suture Zone in the Trans Himalaya, the basin consists of lacustrine deposits ranging in age from late Pleistocene to Holocene [3]. The Lamayuru palaeolake was developed due to damming of Lamayuru River by tectonically triggered landslide [3]. The sediments of Lamayuru palaeolake are more than $100 \mathrm{~m}$ thick and consists of carbonaceous mud, sand, silty clay and matrix supported breccia [4] [5] [6]. The sharp contact between Lamayuru flysch consisting breccia dominated limestone and overlying lacustrine silts indicates that the lake was massive and resistant enough to cause an immediate flooding of the valley and to initiate lacustrine sedimentation. The present discharge of northeast flowing Lamayuru River is very low. During the Lamayuru palaeolake event, the discharge might have been higher with more humid periglacial conditions [3]. The basal lacustrine deposits are represented by white chalky beds that crop out strikingly along the valley walls. These beds are composed of mud, silt and fine sand and are horizontally stratified and are rich in organic debris. The occurrence of gastropods and ostracods in the centre of the valley suggests the shallower depth of the lake.

\section{Geological Setup}

Lamayuru basin (N34 $17^{\prime} 05^{\prime \prime}$ lat. and E76 $47^{\prime} 00^{\prime \prime}$ long.) (Figure 1) is located at an altitude of $3600 \mathrm{~m}$ in the Ladakh region and is very well connected by metalled

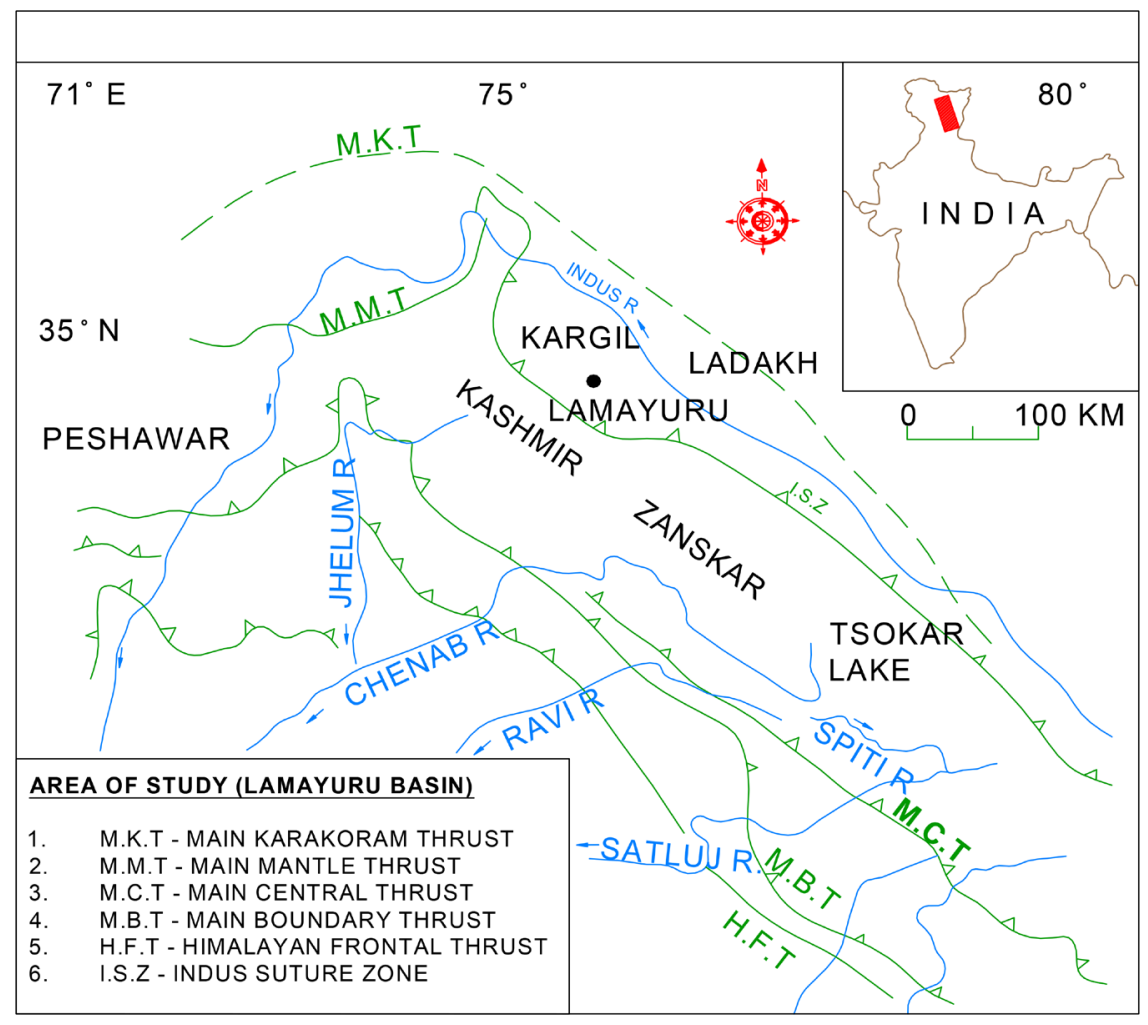

Figure 1. Location map of Lamayuru along with tectono-stratigraphic divisions in NW Himalaya. Map modified after [6]. 
road from Srinagar to Leh. The present environment of the basin is characterized by a semi-arid continental climate with a total of about $150 \mathrm{~mm}$ rainfall per year.

The Lamayuru site extends along a small easterly flowing tributary of the Yapola River. The Yapola River carries glacial melt water and drains from Spongtang range toward the Indus River, a few kilometers downstream of Khalsi. Covering approximately 75 sq. $\mathrm{km}$ area, the Lamayuru watershed extends over a steep alpine terrain, from $3200 \mathrm{~m}$ near the Yapola River confluence with the Lamayuru River to more than $5500 \mathrm{~m}$ along the Nindam ridge and the Prinkiti ridge. The Lamayuru River flows from Nindam ridge and meets Chankhar stream coming from Prinkiti ridge at Lamayuru basin. More ahead about $7 \mathrm{~km}$. from Lamayuru village to Leh, the Lamayuru River meets the Yapola River coming from Wanla and then after Lamayuru River flows and joins the Indus River near Khalsi (Figure 2). The Lamayuru River has cut deep into the sedimentary sequence of Indus flysch of Triassic-Jurassic age. The Lamayuru River has further helped in exposing the well interbedded sequence of alternate red, green and cherty shales along with the basic rocks. These rocks are highly folded and faulted. Mesoscopic to megascopic folds can be seen all along the banks of the Lamayuru River.

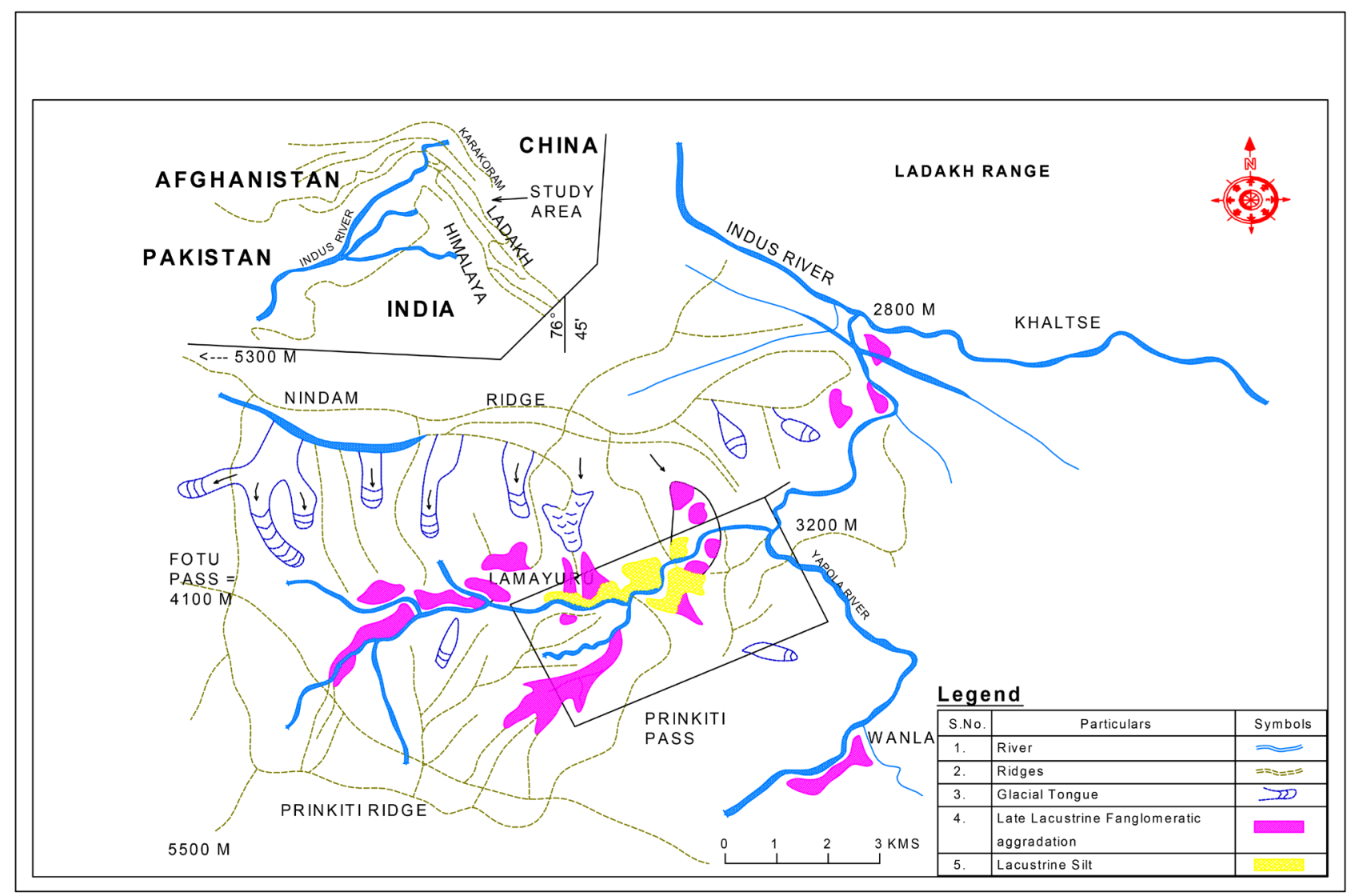

Figure 2. Map showing the Location (Boxed) of varvites (glacio-lacustrine sediments) deposited in basal as well as top beds in Lamayuru basin, Ladakh. Map modified after [3]. 


\section{Previous Work}

For more than a century, travellers following the ancient trail joining Srinagar to Leh have remarked on the spectacular lacustrine deposits of Lamayuru. In 1848, Cunningham recognized the sediments as the undoubted evidence for a huge lake that existed at a relatively recent epoch. According to the legend reported by Cunningham [7], the lake was drained out by the lama Naropa when he founded the first Buddhist monastery at Lamayuru. Drew [8] was the first to point out the abundance of alluvium interfingered with lacustrine silts. Dainelli [9] suggested the lake was formed during a "fairly old glacial period" at a time when a glacier tongue descended the adjacent Yapola valley and dammed the small Lamayuru tributary before converging with the Indus River. Pandey [10] mentioned again the legend specifying that the Lamayuru Lake had clear waters which were rapidly drained.

Burgisser et al. [11] suggested that this sudden draining probably caused catastrophic event downstream and that caused the erosion of the lacustrine sediments from the centre of the valley. Bagati et al. [12], Fort et al. [3] and Shukla et al. [6] studied the sedimentation pattern in the basin and gave different ages for initiation of lacustrine sedimentation in the basin. Kotlia et al. [13] studied the palaeomagnetic properties of the lake sediments. Kotlia et al. [5] recorded the minor reversal polarity event at Lamayuru dated $35.5 \pm 0.6 \mathrm{ka}$ B.P. Kachroo et al. [14], Malik and Shah [15] and Mathur and Kotlia [16] worked over the microinvertebrates including molluscs and ostracods deposited in the lake sediments. Kachroo et al. [14] gave the brief paleoecological implication of fauna of Lamayuru lake sediments and showed that the ostracod assemblages from Lamayuru have close affinities with the similar ostracods described from the upper Karewa Formation of Kashmir. Malik and Shah [15] reported various ostracod taxa from Lamayuru especially the Parastenocypris cf. simils species, a central Asian form that is reported for the first time in India. Mathur and Kotlia [16] reported molluscs (bivalves and gastropods) and ostracodes from the late Quaternary fluvio-lacustrine sediments of Lamayuru and showed that the abundance of Pisidium sp. (bivalves) in the lowermost horizon of lake sediments indicates typical lacustrine environment. Ranhotra et al. [17] studied the palynological analysis of the paleaolake sediments and described that the prevailing semi-arid climate of this region has been continuing at least from prior to $35 \mathrm{ka}$ B.P. and before it climate was comparatively less arid.

\section{Observations}

During the field investigations, the Lamayuru basin was studied for the deposition of varvites at different locations. Ten localities of varvites were visited and their geographical coordinates recorded (Figure 2, Table 1). The varvites are common throughout the lacustrine depositon as these are found from the base level to the top of the palaeolake deposits. The lowest altitude where the varvites are found is Location 4 that is situated at an elevation of $10,620 \mathrm{ft}$. The varvites 
Table 1. Location of varvite deposits in the Lamayuru palaeolake basin.

\begin{tabular}{|c|c|c|c|c|}
\hline S. No. & Varvites & Latitude & Longitude & Altitude (ft.) \\
\hline 1. & Location 1 & 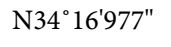 & E76 $46^{\prime} 795^{\prime \prime}$ & 10,858 \\
\hline 2. & Location 2 & 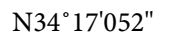 & E76 $47^{\prime} 092^{\prime \prime}$ & 10,650 \\
\hline 3. & Location 3 & N34 $17^{\prime} 052^{\prime \prime}$ & E76 $47^{\prime} 092^{\prime \prime}$ & 10,630 \\
\hline 4. & Location 4 & 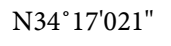 & E76 $47^{\prime} 158^{\prime \prime}$ & 10,620 \\
\hline 5. & Location 5 & 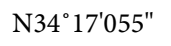 & E76 $47^{\prime} 249^{\prime \prime}$ & 10,680 \\
\hline 6. & Location 6 & 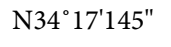 & E76 $47^{\prime} 360^{\prime \prime}$ & 10,673 \\
\hline 7. & Location 7 & N34 $16^{\prime} 998^{\prime \prime}$ & E76 $47^{\prime} 175^{\prime \prime}$ & 10,724 \\
\hline 8. & Location 8 & N341'ㄷ' $944^{\prime \prime}$ & E76 $47^{\prime} 411^{\prime \prime}$ & 10,730 \\
\hline 9. & Location 9 & $\mathrm{~N} 34^{\circ} 16^{\prime} 429^{\prime \prime}$ & E76 $47^{\prime} 452^{\prime \prime}$ & 10,750 \\
\hline 10. & Location 10 & 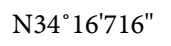 & E76 $47^{\prime} 719^{\prime \prime}$ & 11,000 \\
\hline
\end{tabular}

are also found near the top of the palaeolake deposits e.g., Location 10 at 11,000 $\mathrm{ft}$. In between from base to the top there are also thick varve deposits as recorded in Location 1 to Location 10.

The lake deposits also consist of carbonaceous mud, silty clay, sand with pebbly horizons and matrix supported breccia. The country rocks (shale, silt and sandstone) are weathered and shattered at their contact with the overlying lacustrine sediments. The basal part of the section is non-laminated, carbonaceous mud, containing gastropod shells. Thereafter, silty clay/mud intercalated with sand layers are dominant (Figure 3).

The top of the palaeolake deposits is covered by the mud cracks, whereas the surroundings are covered by post lacustrine alluvium represented by the terraces along the Lamayuru river as well as colluvial deposition represented by fanglomeratic shales (Figure 4).

\section{Field Observations}

1) Varvites (Figure 3(a)) of alternate grey and red colour are seen in the basal deposited beds of the lake basin which show glacio-lacustrine conditions during the initiation of sedimentation in the Lamayuru basin.

2) Mud-cracks (Figure 3(b)) are also seen on the top of the lake sediments which show the rapid drain out of the water during lacustrine conditions.

3) Lake deposits consist of sand, silty clay, carbonaceous mud (Figure 3(c)).

4) Lake sediments comprising sand, clay and mud can be seen from a distance on account of their colour contrast with grey Triassic-Jurassic age bedrock (Figure 3(d)).

5) The Lamayuru River meets Chankhar stream near Lamayuru village and further meets the Yapola River from Wanla at $7 \mathrm{~km}$ distance from Lamayuru village to Leh (Figure 3(e)).

6) Alluvial terraces along the Lamayuru River (now dried up) near Lamayuru village (Figure $3(\mathrm{f})$ ). 

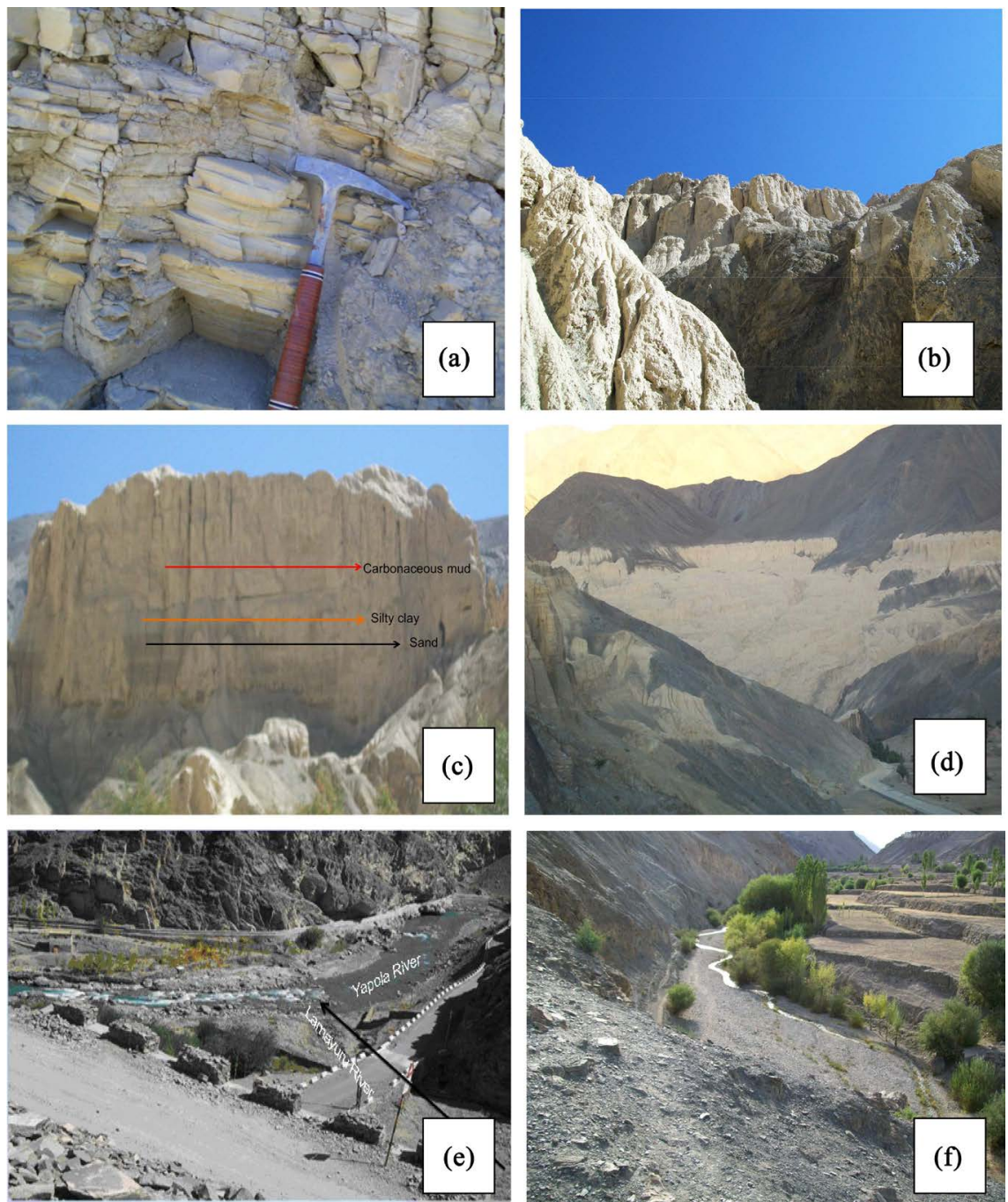

Figure 3. Field photographs. (a) shows varvites in the basal lake beds. (b) shows mud cracks on the top of lake sediments. (c) shows sand silt and clay beds. (d) shows basal Triassic-Jurassic rocks different from lake sediments. (e) shows confluence of Lamayuru River (now dried up) with Yapola River. (f) shows view of Lamayuru River (now dried up) with associated river terraces near Lamayuru village.

The above observations define the general geological investigations in and around Lamayuru palaeolake basin.

\section{Conclusion}

From the field observations, it is quite clear that the varvites compose much part of the lacustrine deposition. These varvites clearly depicts glacio-lacustrine deposition. The Lamayuru basin was fed by the Lamayuru River coming from glacial ridge e. g., Namikala Ridge which is later on joined by a small river coming from Prinkiti Ridge and further ahead meets the mighty Indus River. However the deposits surrounding the varvites are a product of fluvio-deltaic (alluvium) as well as colluvial depositional environment (shattering of fanglomeratic shales) in Lamayuru Lake during its deposition. Thus the Lamayuru watershed is 


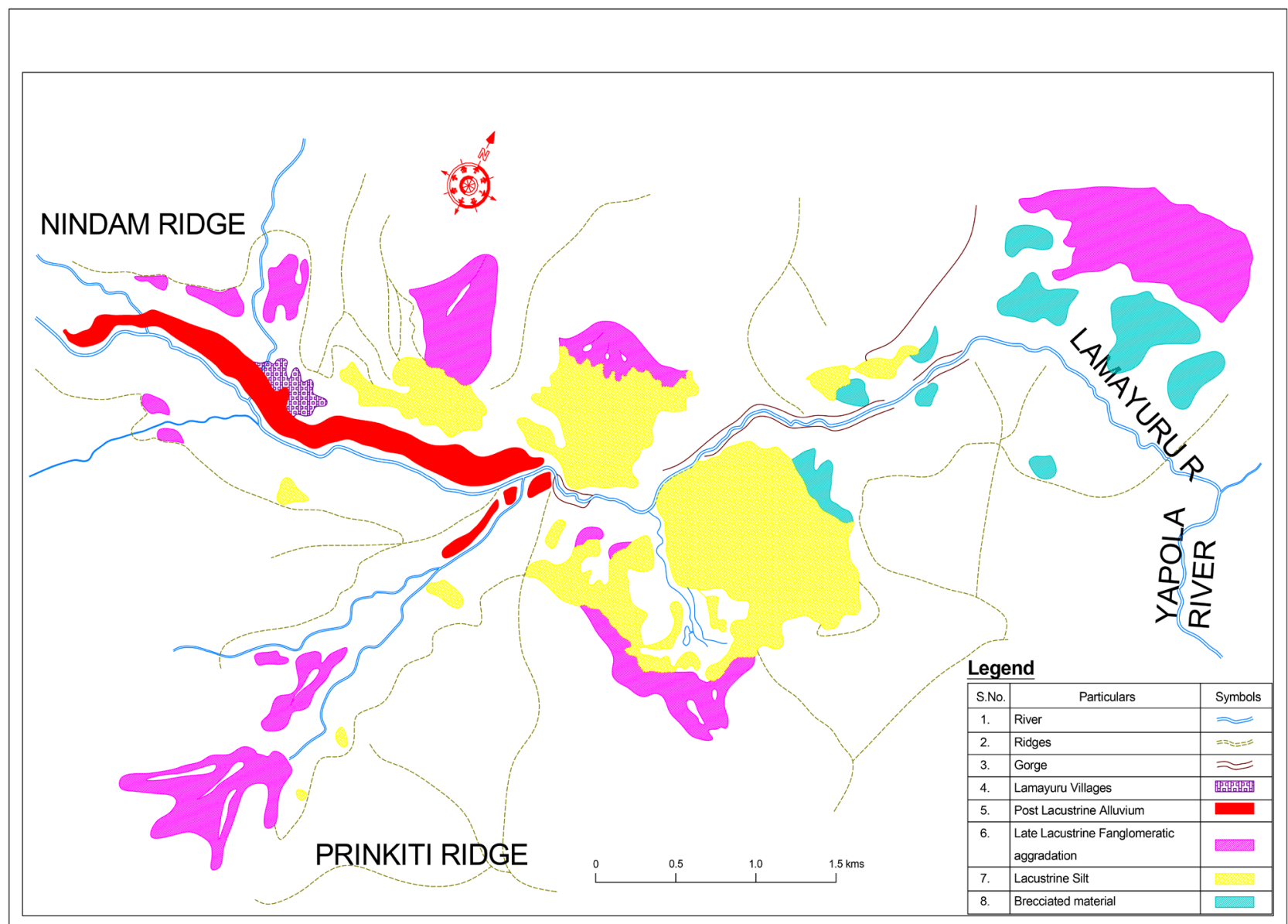

Figure 4. Map of Lamayuru Palaeolake basin (Boxed from Figure 2) showing lacustrine deposits surrounded by different other deposits. Map modified after [3].

deposited by different types of palaeo-deposits including varvites in the main Lamayuru palaeolake basin and younger alluvium in the form of terraces along the Lamayuru River and the surrounding colluvial deposits. The research study shows the prevalence of glacio-lacustrine conditions during the major part of depositional history as evidenced by the dominance of varves in these deposits.

\section{Acknowledgements}

The field work was carried out in the summers of the years 2009, 2010 and 2011 and the research work was carried out in the Department of Geology, University of Jammu, Jammu and Kashmir. The final documentation of the research paper was carried out in Department of Geology, Kurukshetra University, Kurukshetra. The corresponding author is thankful to Sh. Subhash Sharma for his assistance during the field observations.

\section{Conflicts of Interest}

The authors declare no conflicts of interest regarding the publication of this paper. 


\section{References}

[1] Thakur, V.C. (1981) Regional Framework Geodynamic Evolution of the Indus-Tsangpo Suture Zone in the Ladakh Himalaya. Earth Science, 72, 89-97. https://doi.org/10.1017/S0263593300009925

[2] Thakur, V.C. (1980) Tectonics of the Central Crystallines of Western Himalaya. Tectonophysics, 62, 141-151. https://doi.org/10.1016/0040-1951(80)90142-0

[3] Fort, M., Burbank, D.W. and Freytet, P. (1989) Lacustrine Sedimentation in a Semiarid Alpine Setting: An Example from Ladakh, NW Himalaya. Quaternary Research, 31, 332-350. https://doi.org/10.1016/0033-5894(89)90041-0

[4] Bagati, T.N. and Thakur, V.C. (1998) Quaternary Basins of Ladakh and Lahaul Spiti in North-Western Himalaya. Current Science, 64, 898-903.

[5] Kotlia, B.S., Bhalla, M.S., Shah, N. and Rajagopalan, G. (1998) Palaeomagnetic Results from the Pleistocane-Holocene Lake Deposits of Bhimtal and Bhowali (Kumaun Himalaya) and Lamayuru (Ladakh Himalaya) with Reference to the Reversal Events. Journal Geological Society of India, 51, 7-20.

[6] Shukla, V.K., Kotlia, B.S. and Mathur, P.D. (2002) Sedimentation Pattern in a Trans-Himalayan Quaternary Lake at Lamayuru (Ladakh), India. Sedimentary Geology, 148, 405-424. https://doi.org/10.1016/S0037-0738(01)00160-9

[7] Cunningham, A. (1854) Ladakh, Physical, Statistical and Historical. London.

[8] Drew, F. (1875) Jummoo and Kashmir Territories. Stanford, London.

[9] Dainelli, G. (1922) Studi sul glaciale. In: Spedizione italiane de Fillipi nell'Himalaia Caracorum e Turchestan Cinese (1931-1914). Sec. II. Resultati Geologici e Geografici, 3(1), N. Zanchelli, Bologna.

[10] Pandey, K. (1975) A Brief History of Lamayuru Monastery. Hindu Art Press, Godowlja.

[11] Burgisser, H.M., Gansser, A. and Pika, J. (1982) Late Glacial Lake Sediments of the Indus Valley Area, North-Western Himalaya. Eclogae Geologicae Helveticae, 75, 51-63.

[12] Bagati, T.N., Mazari, R.K. and Rajagopalan, G. (1996) Paleotectonic Implications of Lamayuru Lake (Ladakh). Current Science, 71, 479-482.

[13] Kotlia, B.S., Shukla, U.K., Bhalla, M.S., Mathur, P.D. and Pant, C.C. (1997) Quaternary Fluvio-Lacustrine Deposits of the Lamayuru Basin, Ladakh Himalaya: Preliminary Multidisciplinary Investigations. Geologic Magazine, 134, 807-812. https://doi.org/10.1017/S0016756897007826

[14] Kachroo, R.K., Kulshreshta, S.K. and Gupta, V.J. (1984) Upper Pleistocene Ostracods from Lamayuru Ladakh. Geoscience Journal, 5, 63-68.

[15] Malik, M.A. and Shah, S.K. (1990) Quaternary Ostracodes from Ladakh, J\&K, India. Journal of Paleontological Society of India, 35, 143-149.

[16] Mathur, P.D. and Kotlia, B.S. (1999) Late Quaternary Microinvertebrate Assemblages from Fluvio-Lacustrine Sediments of the Lamayuru Basin, Ladakh Himalaya. Journal Geological Society of India, 53, 173-180.

[17] Ranhotra, P.S., Bhattacharya, A. and Kotlia, B.S. (2007) Vegetation and Climatic Changes around Lamayuru, Trans-Himalaya during the Last 35 kyr B.P. The Palaeobotanist, 56, 117-126. 